\title{
THE TEMPORAL STABILITY OF THE VARIABILITY IN APPARENT SOIL ELECTRICAL CONDUCTIVITY
}

\author{
ESTABILIDADE TEMPORAL DO PADRÃO DE VARIABILIDADE ESPACIAL DA \\ CONDUTIVIDADE ELÉTRICA APARENTE DO SOLO
}

\author{
Wilker Nunes MEDEIROS ${ }^{1}$; Daniel Marçal de QUEIROZ $^{2}$; \\ Domingos Sárvio Magalhães VALENTE ${ }^{2}$; Francisco de Assis de Carvalho PINTO²; \\ Christiane Augusta Diniz MELO ${ }^{3}$
}

1. Estudante de Doutorado do Programa de Pós-graduação em Engenharia Agrícola, Universidade Federal de Viçosa - UFV, Viçosa, MG, Brasil. wilker.medeiros@ufv.br 2. Professor, Doutor, Departamento de Engenharia Agrícola - UFV, Viçosa, MG, Brasil; 3.

Doutora em Fitotecnia - UFV, Viçosa, MG, Brasil.

\begin{abstract}
Apparent soil electrical conductivity $\left(\mathrm{EC}_{\mathrm{a}}\right)$ measurements can be used for crop management in precision agriculture. However, $\mathrm{EC}_{\mathrm{a}}$ is a soil attribute that presents spatial and temporal variability. It is affected by a group of factors that act simultaneously on the soil, such as the soil texture, moisture content, organic matter content and ionic concentrations in the soil solution, which complicates analysis. For soil and crop management, it is important to determine whether the pattern of the $\mathrm{EC}_{\mathrm{a}}$ spatial variability changes over time. Thus, $\mathrm{EC}_{\mathrm{a}}$ measurements have the potential for delimiting management zones that are stable over time. The objective of this work was to determine whether the spatial variability pattern of $\mathrm{EC}_{\mathrm{a}}$ is maintained over time and under different soil conditions. To this end, the $\mathrm{EC}_{\mathrm{a}}$ was measured at different soil depths using a portable sensor on two crop fields. The first step was to measure and generate an $\mathrm{EC}_{\mathrm{a}}$ map for each area. By defining a path with the maximum $\mathrm{EC}_{\mathrm{a}}$ variability, 50 sampling points were located on each field. The $\mathrm{EC}_{\mathrm{a}}$ values were measured on 20 different dates in the $0-20 \mathrm{~cm}, 0-40 \mathrm{~cm}$ and $0-60 \mathrm{~cm}$ soil layers. The soil water content was measured at the same points in the $0-20 \mathrm{~cm}$ layer on the same dates. The temporal stability of the $\mathrm{EC}_{\mathrm{a}}$ was analyzed using spatial and temporal variability maps, a correlation analysis and a coefficient of variation over time for each field. In both areas, the $\mathrm{EC}_{\mathrm{a}}$ exhibited temporal stability in the spatial pattern variability at the three evaluated depths, even though the soil water content values changed on each date. $\mathrm{EC}_{\mathrm{a}}$ determination presents an important alternative for mapping agricultural fields for crop management in precision agricultural systems.
\end{abstract}

KEYWORDS: Precision agriculture. Soil mapping. Sensors in agriculture.

\section{INTRODUCTION}

Precision agriculture has been intensively developed in recent years, especially due to rapid advances in information technology and Geographic Information Systems (GIS). However, the mapping of chemical, physical and physicochemical soil properties remains a problem that has not been completely resolved. A large number of sampling points are necessary to provide sufficient information to generate a precise map of soil attributes. The acquisition and analysis of these samples are expensive and time-consuming task, which in some cases renders the process unfeasible. To overcome this problem, new technologies for direct and remote sensing have been developed for the acquisition of relevant spatial information from production fields to reduce the money and time expended for soil map generation.

Among the new sensing technologies employed in precision agricultural systems, the apparent soil electrical conductivity $\left(\mathrm{EC}_{\mathrm{a}}\right)$ has become an important tool for understanding the spatial variability of agricultural production systems. Many studies have reported the relationship of $\mathrm{EC}_{\mathrm{a}}$ with other soil attributes, including texture, water content, salinity, $\mathrm{pH}$, cation exchange capacity (TERRÓN et al., 2011; HEIL; SCHMIDHALTER, 2011; ISLAM et al., 2012; SERRANO et al., 2012; VALENTE et al., 2012a) and crop yield (MANN et al., 2011; ALCÂNTARA et al., 2012). Therefore, $\mathrm{EC}_{\mathrm{a}}$ mapping may provide a rapid and effective means of identifying areas with similar features at a lower cost, allowing for needsbased management (FAROOQUE et al., 2012; VALENTE et al., 2012b).

It is important to understand how $\mathrm{EC}_{\mathrm{a}}$ spatial variability is related to other soil attributes of agronomic importance in precision agricultural systems. This statement is especially true when an $\mathrm{EC}_{\mathrm{a}}$ map is used to delimit management zones (FAROOQUE et al., 2012; VALENTE et al., 2012 $\mathrm{ab}$ ). The temporal variability of this soil attribute is important information when using an $\mathrm{EC}_{\mathrm{a}}$ map. In applications in which management zones are generated, it is important that the pattern of $\mathrm{EC}_{\mathrm{a}}$ spatial variability does not change over time 
(HARTSOCK et al., 2000; FARAHANI; BUCHLEITER, 2004; ISLAM et al., 2012).

Grain-producing regions in Brazil have two crops per year, and the interval between harvesting one crop and planting the next is usually very short; therefore, the mapping of $\mathrm{EC}_{\mathrm{a}}$ must be performed within this interval irrespective of the soil condition. For this reason, the generated maps should depict similar patterns of $\mathrm{EC}_{\mathrm{a}}$ spatial variability regardless of the soil moisture and ambient conditions (HARTSOCK et al., 2000; FARAHANI; BUCHLEITER, 2004; ISLAM et al., 2012). If this condition is not met, it would be necessary to repeat the management zone definition process immediately before planting each crop, which would result in higher costs and more time required for managing the system.

A study of non-saline soils indicated that the $\mathrm{EC}_{\mathrm{a}}$ patterns were influenced more by stable soil attributes such as texture, organic matter and subsurface structure than by dynamic attributes such as soil moisture content and temperature (HARTSOCK et al., 2000; EIGENBERG et al., 2002; ISLAM et al., 2012; SERRANO et al., 2013). Therefore, according Farahani and Buchleiter (2004), although the magnitudes of the absolute values of $\mathrm{EC}_{\mathrm{a}}$ may changes in response to modifications in the soil dynamic properties, it is expected that the pattern of $\mathrm{EC}_{\mathrm{a}}$ spatial variability does not change significantly over time.

Considering the importance of understanding how $\mathrm{EC}_{\mathrm{a}}$ changes over time, the objective of this study was to evaluate the temporal stability of the spatial pattern of $\mathrm{EC}_{\mathrm{a}}$ at different soil depths using a portable $\mathrm{EC}_{\mathrm{a}}$ sensor.

\section{MATERIAL AND METHODS}

\section{Characterization of crop fields}

This study was performed on two fields with different soil textures (EMBRAPA, 2006). The first field (Field 1) had an area of $10,703.72 \mathrm{~m}^{2}$. This field contains sandy clay loam and has a medium texture. The second field (Field 2) had an area of $14,078.68 \mathrm{~m}^{2}$. This field contains a loamy sand soil with a sandy texture.

In a preliminary analysis, $\mathrm{EC}_{\mathrm{a}}$ maps were acquired for both fields. For this process, $\mathrm{EC}_{\mathrm{a}}$ was measured at 203 and 163 points on Field 1 and Field 2 , respectively. The measurements were obtained using a portable device (Landviser ${ }^{\circledR}$ model LandMapper® ERM-02, Texas, USA), which uses the principle of electrical resistivity measured using a probe with four electrodes. The electrodes were configured in a Wenner matrix to measure the depth at $0-20 \mathrm{~cm}$, as described by Corwin and Hedrickx (2002) and Corwin and Lesch (2003). For both fields, the maps shown in Figure 1 were obtained using an ordinary kriging methodology (WEBSTER; OLIVER, 1992), by the softwares GS+, version 9 and Surfer, version 10.

After obtaining the $\mathrm{EC}_{\mathrm{a}}$ map for each field, a path with a wider range of values was drawn, and the locations of 50 experimental sampling points were defined. These points were marked by posts, constituting the sample units in the study (Figure 1). Each unit represented an area of $2 \times 2 \mathrm{~m}$, from which the $\mathrm{EC}_{\mathrm{a}}$ determinations were obtained on different dates.

A determination of the coordinates for each field limit and their respective sampling points was performed using a model ProMark3 Topographical GPS instrument (Magellan®). A post-processed differential correction was performed using GNSS Solutions ${ }^{\circledR}$ software provided by the GPS device manufacturer. A base station of the Brazilian Institute of Geography and Statistics (IBGE) was used for the DGPS correction, and the SIRGAS 2000 datum was used.

\section{Determination of the apparent soil electrical conductivity}

Three probes were prepared for measuring the $\mathrm{EC}_{\mathrm{a}}$ within the sample units at different depths. The electrodes were spaced at 20, 40 and $60 \mathrm{~cm}$ for measuring the $\mathrm{EC}_{\mathrm{a}}$ in the $0-20 \mathrm{~cm}$ layer $\left(\mathrm{EC}_{\mathrm{a}} 20\right), 0$ $-40 \mathrm{~cm}$ layer $\left(\mathrm{EC}_{\mathrm{a}} 40\right)$ and $0-60 \mathrm{~cm}$ layer $\left(\mathrm{EC}_{\mathrm{a}} 60\right)$, respectively.

Twenty measurements of the $\mathrm{EC}_{\mathrm{a}} 20, \mathrm{EC}_{\mathrm{a}} 40$ and $\mathrm{EC}_{\mathrm{a}} 60$ were obtained for each of the fifty sampling units in each field. The measurements were performed between 10/19/2012 and $12 / 19 / 2012$. No more than forty minutes was required to conduct all of the measurements in each field; this procedure minimized the effects of temperature and water content variations on the measured soil attributes.

\section{Determination of the soil moisture content}

The soil moisture content was determined using a thermogravimetric method. On each $\mathrm{EC}_{\mathrm{a}}$ determination date, twenty-five soil samples of deformed structures were collected in the $0-20 \mathrm{~cm}$ layer. The samples were collected at each point having an even identification number (Figure 1) and stored in aluminum moisture content tins. The samples were weighed and dried at $105{ }^{\circ} \mathrm{C}$ for 24 hours to determine the dry mass of the soil. 


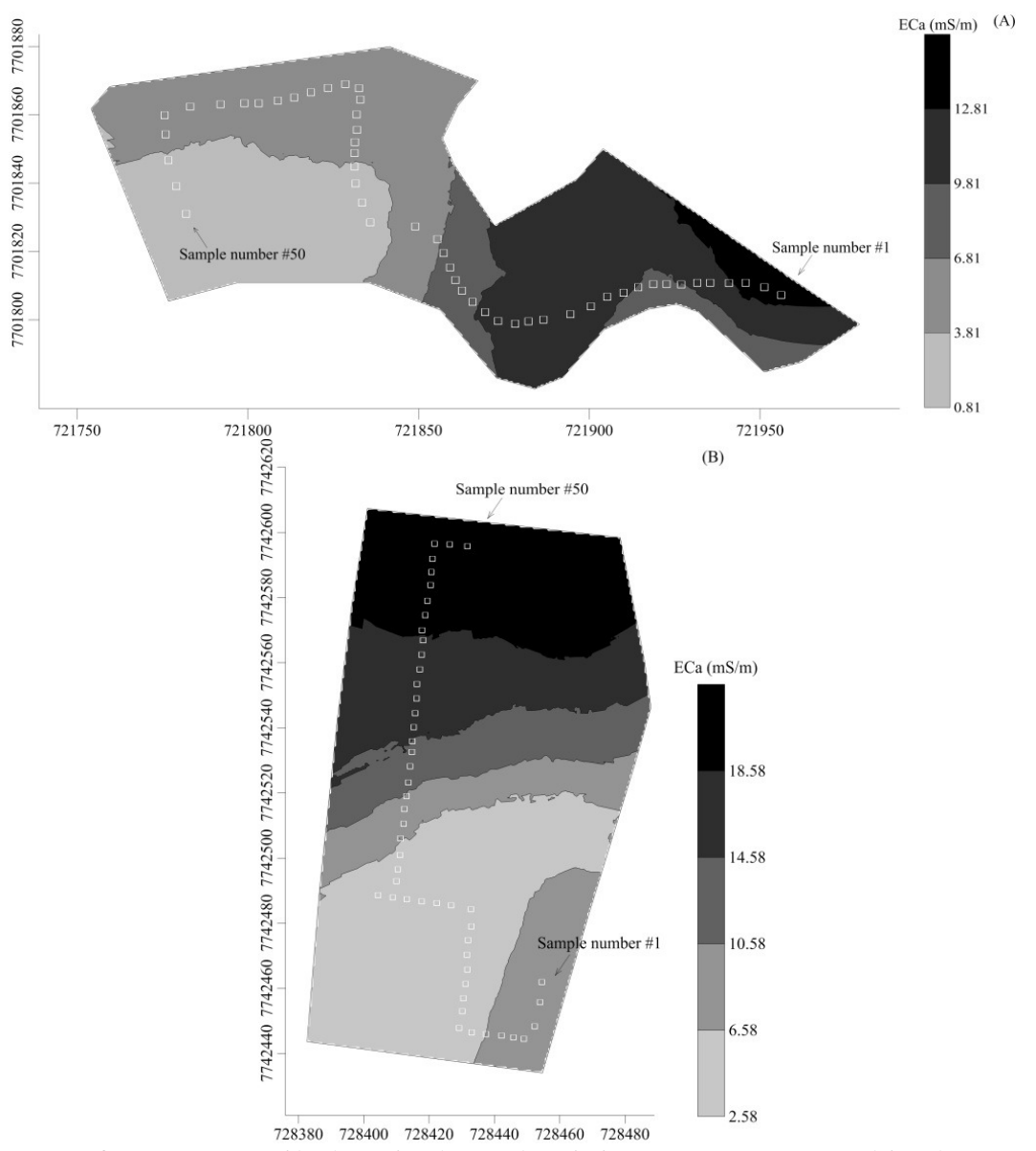

Figure 1. Thematic maps of apparent soil electrical conductivity $\left(\mathrm{EC}_{\mathrm{a}}\right)$ measured in the $0-20 \mathrm{~cm}$ soil layer; the respective sampling unit locations are shown for Field 1 (A) and Field 2 (B).

\section{Analysis of the temporal variability and stability of the apparent soil electrical conductivity}

An initial exploratory analysis of the data was conducted. The methodology proposed by Libardi et al. (1996) was used for checking the measured values by identifying each value classified as a candidate outlier.

After eliminating the outlier values, three different methodologies were used to analyze the variability and temporal stability of $\mathrm{EC}_{\mathrm{a}}$. First, to evaluate the temporal stability of $\mathrm{EC}_{\mathrm{a}}$, a linear correlation analysis between the original $\mathrm{EC}_{\mathrm{a}}$ values from different dates was performed, as suggested by Vachaud et al. (1985) and Kachanoski and De Jong (1988). Pearson correlation coefficients were calculated, and the significance was tested using Student's t-test at 5\% probability.

To complement the data analysis, a chart of the temporal stability was created using the coefficients of variation (CV) determined for all sample units from each measurement date. This was performed using the methodology described by $\mathrm{Li}$ et al. (2007), Blackmore (2000), Shi et al. (2002), Xu et al. (2006) and Serrano et al. (2011). The coefficient of variation was calculated using Equation 1:

$C V_{i}=100 \frac{\sqrt{\frac{n \sum_{t=1}^{t=n} y_{t_{t}}^{2}-\left(\sum_{i=1}^{t=n} y_{i_{t}}\right)^{2}}{n(n-1)}}}{\bar{y}_{i}}$

where $C V_{i}=$ the coefficient of variation of the values measured on different dates for a soil attribute of the $\mathrm{i}^{\text {th }}$ sample unit; $y_{i_{t}}=$ the value of the soil attribute from the $i^{\text {th }}$ sample unit measured on the $\mathrm{t}^{\text {th }}$ date; and $n=$ the number of measured values of the soil attribute.

Li et al. (2007) and Blackmore (2000) used a method based on the coefficient of variation for each sampling point. They suggested that if the coefficient of variation is less than $30 \%$, then there is temporal stability; however, values greater than $30 \%$ are indicative of temporal instability of the analyzed variable. This method was also adopted here to evaluate the coefficient of variation.

Finally, to quantify the temporal variability of the $\mathrm{EC}_{\mathrm{a}}$ spatial patterns in each field, the 
measured values were normalized according to the method of Farahani and Buchleiter (2004) using Equation 2:

$E C_{a(\text { Morm })}=100\left[\frac{E C_{a(a c t a a l)}-E C_{a(\min )}}{E C_{a(\max )}-E C_{a(\min )}}\right]$

where $E C_{a(\text { norm })}=$ the normalized value of the apparent soil electrical conductivity $\left(\mathrm{EC}_{\mathrm{a}}\right)$ on a 0 to 100 scale, calculated for each measurement date and each sample unit; $E C_{a(a \text { otual })}=$ the $\mathrm{EC}_{\mathrm{a}}$ value to be normalized for a defined sample unit; $E C_{a(\max )}=$ the maximum $\mathrm{EC}_{\mathrm{a}}$ value for a defined field and sampling date; and $E C_{a(\min )}=$ the minimum $\mathrm{EC}_{\mathrm{a}}$ value for a defined field and sampling date.

A map with the normalized $\mathrm{EC}_{\mathrm{a}}$ data $\left(\mathrm{EC}_{\mathrm{a}(\text { norm })}\right)$ for each measurement date was elaborated using the software Microsoft Excel 2010, where each sample unit along the selected path is represented by a cell, resulting in 50 cells for each date. The color of each cell represented a range of values, with an $\mathrm{EC}_{\mathrm{a}}$ considered to be low if $0 \leq$ $\mathrm{EC}_{\mathrm{a}(\text { norm })}<33$, medium if $34<\mathrm{EC}_{\mathrm{a} \text { (norm) }}<66$, and high if $67<\mathrm{EC}_{\mathrm{a} \text { (norm) }} \leq 100$ (FARAHANI; BUCHLEITER, 2004). This procedure allowed for a visual analysis of the spatial distribution of the measured $\mathrm{EC}_{\mathrm{a}}$ values using different probes and an analysis of their behavior on each determination date.

\section{RESULTS AND DISCUSSION}
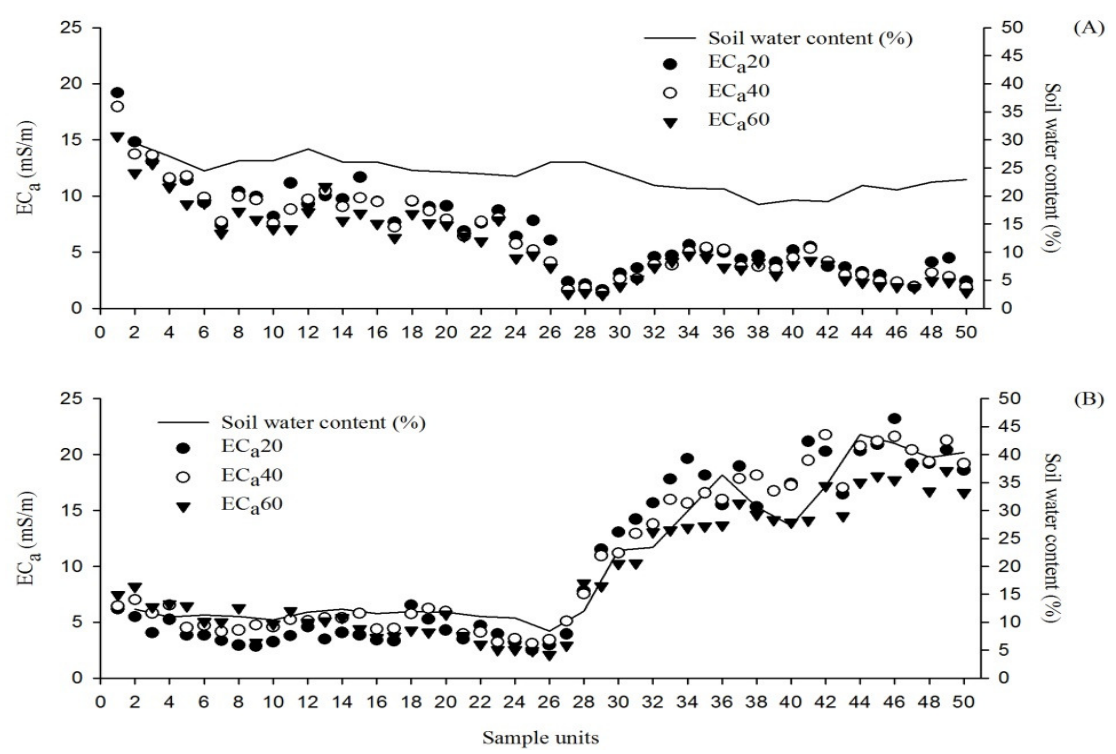

Figure 2. Mean soil moisture content and apparent soil electrical conductivity $\left(\mathrm{EC}_{\mathrm{a}}\right)$ values in the $0-20 \mathrm{~cm}$ layer $\left(\mathrm{EC}_{\mathrm{a}} 20\right), 0-40 \mathrm{~cm}$ layer $\left(\mathrm{EC}_{\mathrm{a}} 40\right)$ and $0-60 \mathrm{~cm}$ layer $\left(\mathrm{EC}_{\mathrm{a}} 60\right)$ in Field 1 (A) and Field $2(\mathrm{~B})$. 
The mean soil moisture content values in the sampling units on the twenty measurement dates ranged from 18.52 to $29.43 \%$ in Field 1 (Figure 2A) and from 8.44 to $43.57 \%$ in Field 2 (Figure 2B). It was also observed that in Field 1, the soil moisture content exhibited lower variability with a slight decrease from sampling unit number 1 to sampling unit number 50 (Figure 2A). In Field 2, the soil moisture content was almost constant from unit number 1 to unit number 28 (Figure 2B). From unit 28 to unit 50, there was an increasing trend in the soil moisture content with an increase in variability. This variation in the soil moisture content was directly related to the textural variation within this area. According Libardi (2005), the clay fraction of the soil has a greater capacity to retain water, and
MEDEIROS, W. N. et al.

thus, the variation in the water content in a field is related to the spatial variability of the clay content. These results demonstrate that the chemical and physical soil properties on Fields 1 and 2 are different and indicate high variation in Field 2

\section{Temporal stability of the apparent soil electrical conductivity \\ The correlation coefficients values} obtained using the measured $\mathrm{EC}_{\mathrm{a}}$ values from different dates were significant and high regardless of the soil layer that were evaluated for both fields (Table 1). This behavior indicates that there was a high temporal stability of the $\mathrm{EC}_{\mathrm{a}}$ in these areas during the analyzed time period.

Table 1. Limits of the Pearson's correlation coefficients for the apparent soil electrical conductivity measured on 20 dates in the $0-20 \mathrm{~cm}$ soil layer, $0-40 \mathrm{~cm}$ soil layer and $0-60 \mathrm{~cm}$ soil layer in Field 1 and Field 2.

\begin{tabular}{lll}
\hline Soil Layer & Field 1 & Field 2 \\
\hline $0-20 \mathrm{~cm}$ & $0,69-0,99$ & $0,76-0,99$ \\
$0-40 \mathrm{~cm}$ & $0,61-0,98$ & $0,75-0,99$ \\
$0-60 \mathrm{~cm}$ & $0,69-0,99$ & $0,71-0,99$ \\
\hline
\end{tabular}

All values were significant at $(\mathrm{p} \leq 0.05)$ for the Student's t-test.

When analyzing the temporal stability charts developed from coefficient of variation $(\mathrm{CVi})$ values (Figure 3), Field 1 exhibited $90.67 \%$ of the data presented with a CVi of the $\mathrm{EC}_{\mathrm{a}}$ less than $30 \%$, indicating a high temporal stability of this soil attribute (Figure 3A). When analyzing the behavior of the $\mathrm{EC}_{\mathrm{a}} 60$ individually, only one of the 50 sample units in the area exhibited a CVi value greater than $30 \%$.

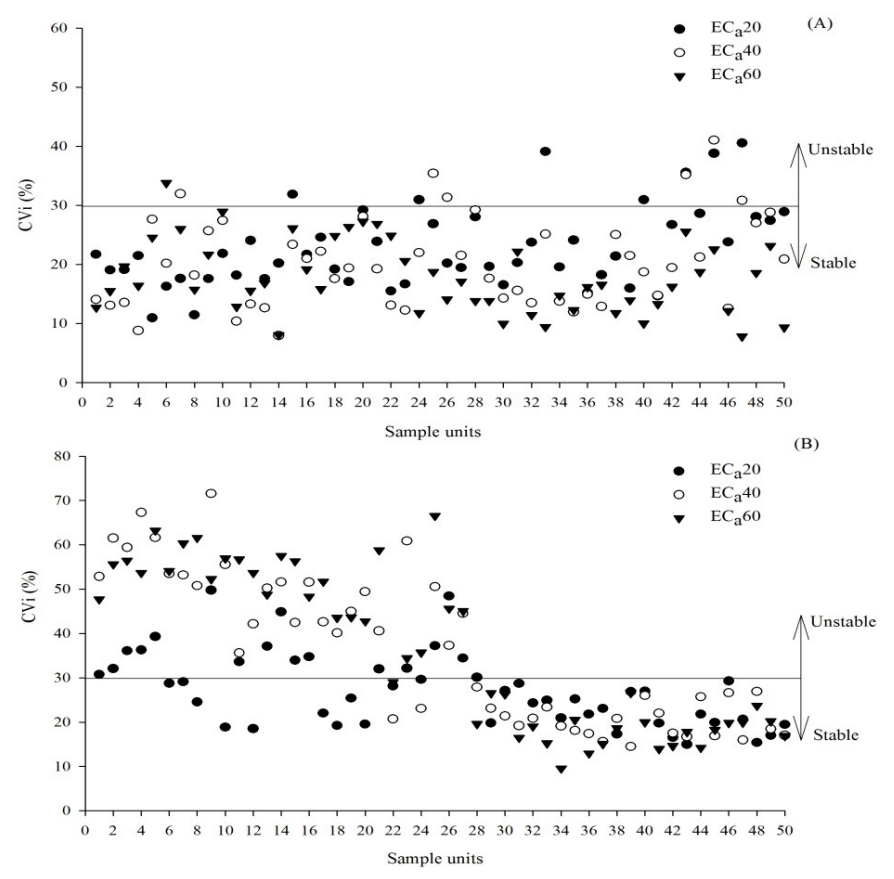

Figure 3. Temporal stability of the apparent soil electrical conductivity established based on the $\mathrm{CV}_{\mathrm{i}}$ values (coefficient of variation for the 20 different dates for the $i^{\text {th }}$ sample unit) in Field 1 (A) and Field 2 (B). 
In Field 2, the $\mathrm{EC}_{\mathrm{a}}$ exhibited temporal instability $(\mathrm{CVi}>30 \%)$ in sample units 1 to 27 , and this stability was greater for $\mathrm{EC}_{\mathrm{a}} 40$ and $\mathrm{EC}_{\mathrm{a}} 60$ (Figure 3B). Follow-up field observations and soil analyses indicated that these sample units had a higher sand content than the other sample units. The greater sand content should have caused greater variation in the soil moisture content as well as the $\mathrm{EC}_{\mathrm{a}}$ values. However, despite the temporal instability $(\mathrm{CVi}>30 \%)$ shown in the analysis, these sample units presented lower $\mathrm{EC}_{\mathrm{a}}$ values than the other sample units (Figure 2). For sample units 28 to 50, the CVi for the $\mathrm{EC}_{\mathrm{a}}$ remained less than $30 \%$ in the three soil layers (Figure 3B), demonstrating its temporal stability.

Moreti et al. (2007) used the same methodology to assess the space-time behavior of gravimetric and volumetric water storage in an Oxisol cultivated with citrus. They found high correlation coefficients for these attributes over a period of three years of data collection. Cambouris et al. (2006) evaluated the temporal stability of $E_{a}$ at the soil surface and in the $0-20 \mathrm{~cm}$ soil layer in two different years and obtained significant coefficients of correlation equal to 0.78 and 0.90 . These authors emphasized that the strong correlations between the different $\mathrm{EC}_{\mathrm{a}}$ measurements indicated low temporal variability, suggesting that $\mathrm{EC}_{\mathrm{a}}$ is a good metric for identifying temporally stable management zones.

In a study of the patterns of $\mathrm{EC}_{\mathrm{a}}$ in coastal saline soil in a province of China, Li et al. (2007), found that regions with a higher salinity exhibited $\mathrm{EC}_{\mathrm{a}}$ temporal variability $(0<\mathrm{CVi}<30 \%)$, whereas regions with low salinity patterns exhibited unstable temporal variability $(\mathrm{CVi}>30 \%)$. This behavior is different from that observed in this present study. The reason for this difference may be linked to the difference in soil composition. The CVi determination approach has been used to analyze not only the temporal variability of the $\mathrm{EC}_{\mathrm{a}}$ but also the temporal stability of crop yields (BLACKMORE, 2000); soil attributes such as pH, P, K and Mg (SHI et al., 2002); dry matter yield and nitrogen content in forage grasses (XU et al., 2006); and yield and phosphorus concentration in pastures (SERRANO et al., 2011).

\section{Spatio-temporal variability of the apparent soil electrical conductivity}

Visual assessments of the $\mathrm{EC}_{\mathrm{a}}$ spatiotemporal variability maps revealed a similar pattern of spatial variability on different dates and in different layers of analyzed soil in both Field 1 (Figure 4) and Field 2 (Figure 5). These maps show that the three classes of normalized $\mathrm{EC}_{\mathrm{a}}$ changed only slightly over time. The location of the normalized $\mathrm{EC}_{\mathrm{a}}$ values in the $0-33 \%$ class is more stable than in the other two bands. The results were similar to those reported by Farahani and Buchleiter (2004) in a study of three irrigated sandy soil fields; they verified that classes with low, medium and high values of normalized $\mathrm{EC}_{\mathrm{a}}$ did not change location over a period of four years. 

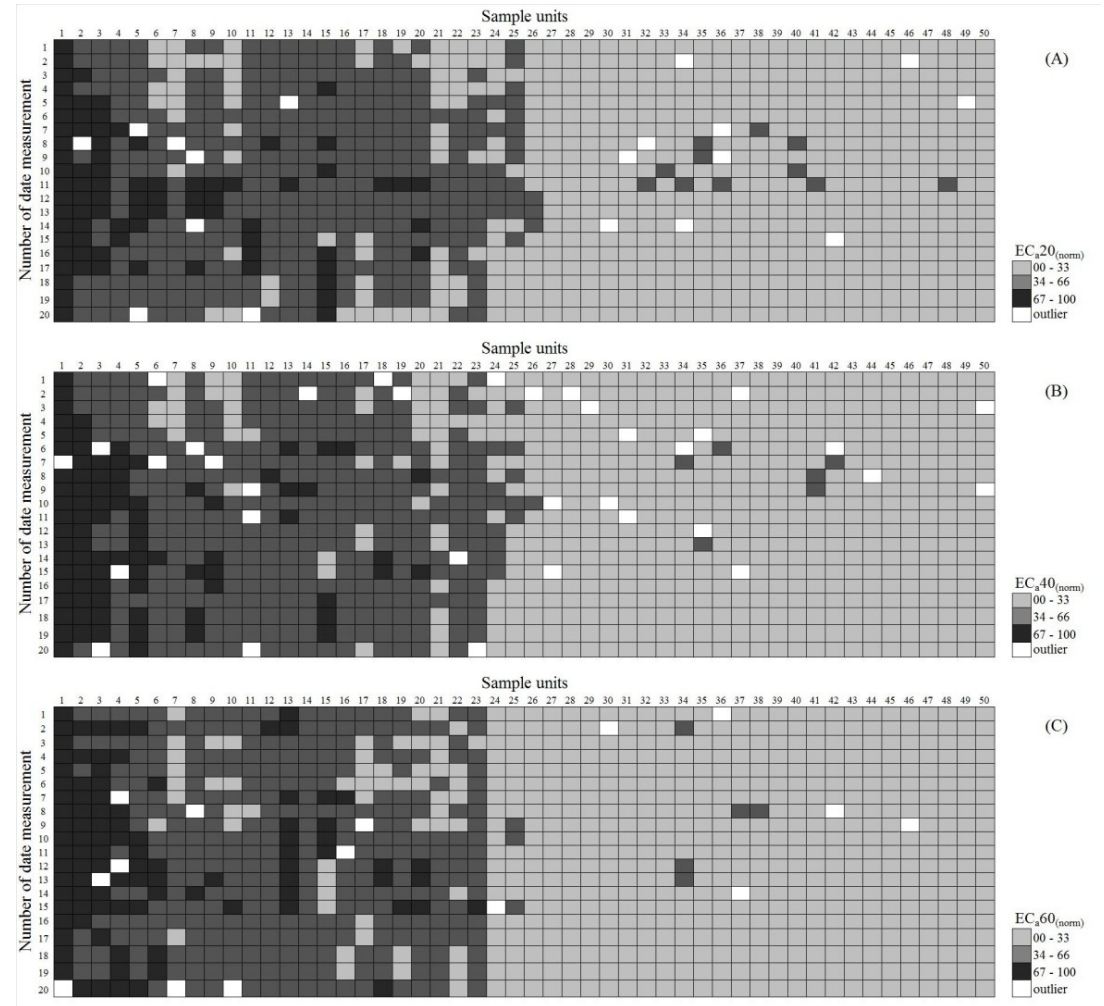

Figure 4. Representation of the spatial pattern of variation of the apparent soil electrical conductivity $\left(\mathrm{EC}_{\mathrm{a}}\right)$ on the 20 measurement dates for each of the 20 sampling units of Field 1 in the $0-20 \mathrm{~cm}(\mathrm{~A}), 0-40$ $\mathrm{cm}(\mathrm{B})$ and $0-60 \mathrm{~cm}$ soil layers (C).
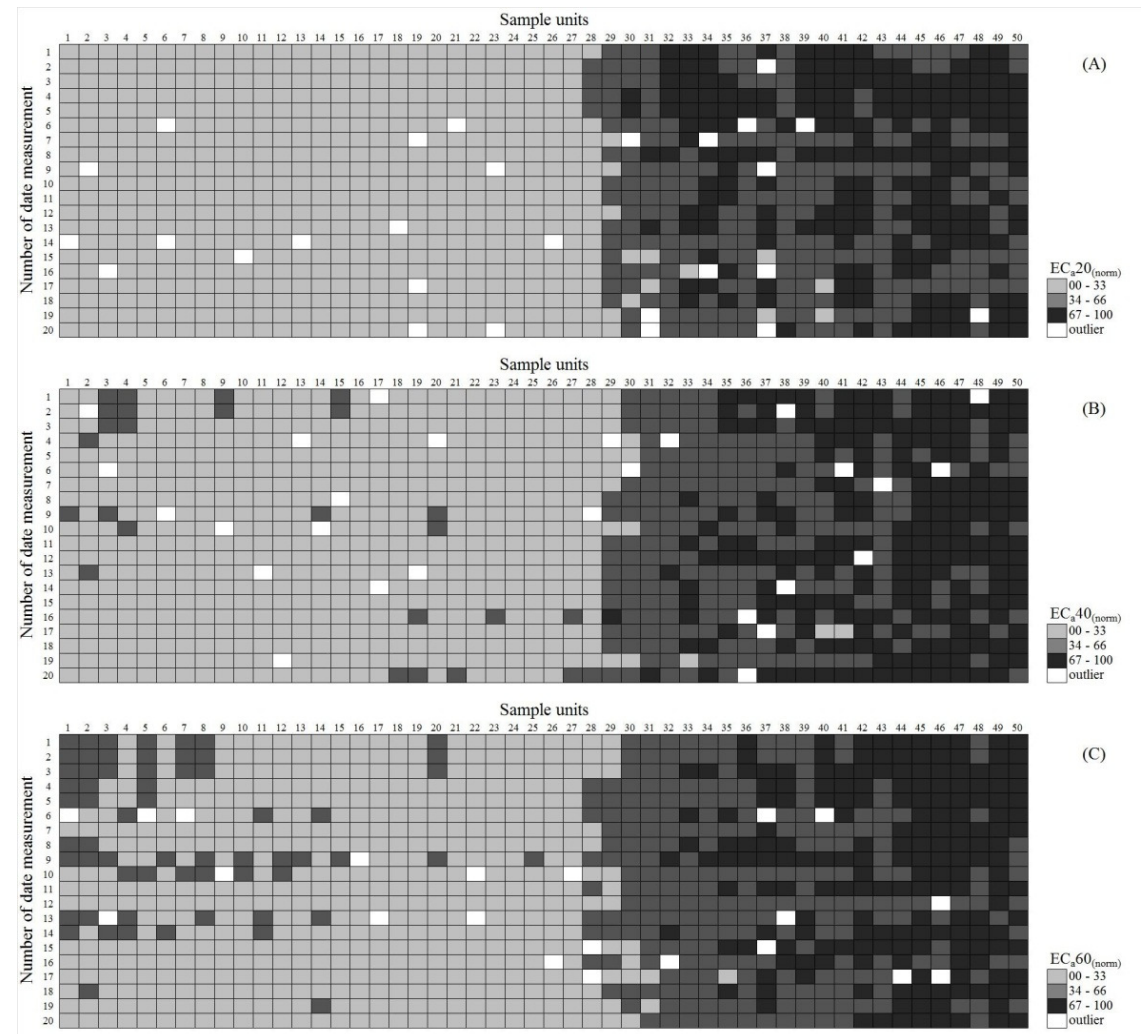

Figure 5. Representation of the spatial pattern of variation of the apparent soil electrical conductivity $\left(\mathrm{EC}_{\mathrm{a}}\right)$ on the 20 measurement dates for each of the 20 sampling units of Field 2 in the $0-20 \mathrm{~cm}(\mathrm{~A}), 0-40$ $\mathrm{cm}(\mathrm{B})$ and $0-60 \mathrm{~cm}$ soil layers (C). 


\section{CONCLUSIONS}

The apparent soil electrical conductivity $\left(\mathrm{EC}_{\mathrm{a}}\right)$ exhibited a temporally stable pattern of spatial variability for the three studied soil depths on two different fields, one presenting a sandy clay loam textured soil and the other presenting a loamy sand soil.

The pattern occurred despite variations in the water content of the soil during the study period. Measurements of $\mathrm{EC}_{\mathrm{a}}$ using a portable meter proved to be a reasonable alternative for mapping agricultural fields, allowing for the identification of regions with similar characteristics that can be managed with precision agriculture.

\section{ACKNOWLEDGMENTS}

The authors thank FAPEMIG (The Minas Gerais State Foundation for Research) and CNPq (The Brazilian National Counsel for Research and Development) for their financial support of this work.

RESUMO: A determinação da condutividade elétrica aparente do solo $\left(\mathrm{CE}_{\mathrm{a}}\right)$ pode auxiliar no gerenciamento da atividade agrícola quando adotada a agricultura de precisão. No entanto, ela é afetada por um conjunto de fatores que atuam simultaneamente no solo e que se alteram tanto no espaço quanto no tempo, como, por exemplo, a textura, o teor de água do solo, a concentração iônica da solução do solo, a matéria orgânica, dificultando a interpretação dos resultados. Buscando-se compreender se a estrutura espacial desse atributo é mantida com o decorrer do tempo e sob diferentes condições edáficas, esse trabalho foi realizado com o objetivo de analisar a estabilidade temporal do padrão espacial da $\mathrm{CE}_{\mathrm{a}}$. Para isso, a condutividade elétrica aparente do solo foi determinada em diferentes profundidades do solo usando um sensor portátil de contato direto em duas áreas distintas. O primeiro passo foi determinar a condutividade elétrica aparente do solo e obter o mapa de $\mathrm{CE}_{\mathrm{a}}$ de cada área. Depois, demarcou-se 50 pontos amostrais buscando-se um caminho de máxima variabilidade da $\mathrm{CE}_{\mathrm{a}}$. Então, a $\mathrm{CE}_{\mathrm{a}}$ foi determinada em 20 datas diferentes nas camadas de solo de $0-20 \mathrm{~cm}, 0-$ $40 \mathrm{~cm}$ e $0-60 \mathrm{~cm}$ de profundidade. $\mathrm{O}$ teor de água do solo foi determinado na camada de $0-20 \mathrm{~cm}$ de profundidade, nas mesmas datas de determinação da $\mathrm{CE}_{\mathrm{a}}$. A estabilidade temporal da $\mathrm{CE}_{\mathrm{a}}$ foi analisada por meio de mapas de variabilidade espaço-temporal, de análises de correlação e do coeficiente de variação ao longo do tempo para cada unidade amostral. Em ambas as áreas a $\mathrm{CE}_{\mathrm{a}}$ apresentou estabilidade temporal do padrão de distribuição espacial para as três profundidades avaliadas, ainda que observadas diferenças no teor de água do solo durante o período do estudo. Portanto, a determinação da $\mathrm{CE}_{\mathrm{a}}$ constitui alternativa interessante para mapeamento de campos agrícolas auxiliando no manejo em sistemas que empregam agricultura de precisão.

PALAVRAS-CHAVE: Agricultura de precisão. Mapeamento do solo. Sensores na agricultura.

\section{REFERENCES}

AIMRUN, W.; AMIN, M.; AHMAD, D.; HANAFI, M.; CHAN, C. Spatial variability of bulk soil electrical conductivity in a Malaysian paddy field: key to soil management. Paddy Water Environment, Germany, v. 5 , n. 2, p. 113-121, 2007. http://dx.doi.org/10.1007/s10333-007-0072-z

ALCÂNTARA, G. R.; REIS, E. F.; QUEIROZ, D. M. Produtividade de culturas correlacionada com condutividade elétrica aparente de um solo sob plantio direto. Revista Agrotecnologia, Anápolis, v. 3, n. 2, p. 62-72, 2012. http://dx.doi.org/10.12971/2179-5959.v03n02a06

BLACKMORE, $S$. The interpretation of trends from multiple yield maps. Computers and Electronics in Agriculture. Netherlands, v. 26, n. 1, p. 37-51, 2000. http://dx.doi.org/10.1016/S0168-1699(99)00075-7

CAMBOURIS, A. N.; NOLIN, M. C.; ZEBARTH, B. J.; LAVERDIÈRE, M. R. Soil management zones delineated by electrical conductivity to characterize spatial and temporal variations in potato yield and in soil properties. American Journal of Potato Research, New York, v. 83, n. 5, p. 381-395, 2006. http://dx.doi.org/10.1007/BF02872015

CORWIN, D. L.; HENDRICKX, J. M. H. Electrical Resistivity: Wenner Array. In: SILVA, J.S. Methods of Soil Analysis Part 4 Physical Methods, Madison, Wisconsin, USA:SSSA Book Series, n. 5, 2002. p. 12821287. 
CORWIN, D. L.; LESCH, S. M. Application of soil electrical conductivity to precision agriculture: Theory, principles, and guidelines. Agronomy Journal, United States, v. 95, n. 3, p. 455-471, 2003.

http://dx.doi.org/10.2134/agronj2003.0455

EIGENBERG, R. A., DORAN, J. W.; NIENABER, J. A.; FERGUSON, R. B.; WOODBURY, B. L. Electrical conductivity monitoring of soil condition and available $\mathrm{N}$ with animal manure and a cover crop. Agriculture, Ecosystems \& Environment, Netherlands, v. 88, n. 2, p. 183-193, 2002. http://dx.doi.org/10.1016/S01678809(01)00256-0

EMBRAPA. Centro Nacional de Pesquisa de Solos (Rio de Janeiro, RJ). Sistema brasileiro de classificação de solos. 2. ed. - Rio de Janeiro : EMBRAPA-SPI, 2006. 306 p.

FARAHANI, H. J.; BUCHLEITER, G. W. Temporal stability of soil electrical conductivity in irrigated sandy fields in Colorado. American Society of Agricultural Engineers, St. Joseph, Michigan, v. 47, n. 1, p. 79-90, 2004. http://dx.doi.org/10.13031/2013.15873

FAROOQUE, A. A.; ZAMAN, Q. U.; SCHUMANN, A. W.; MADANI, A.; PERCIVAL, D. C. Delineating management zones for site specific fertilization in wild blueberry filds. Applied Engineering in Agriculture, United States, v. 28, n. 1, p. 57-70, 2012. http://dx.doi.org/10.13031/2013.41286

HARTSOCK, N. J.; MUELLER, T. G.; THOMAS, G. W.; BARNHISEL, R. I.; WELLS, K. L.; SHEARER, S. A. Soil electrical conductivity variability. In: INTERNATIONAL CONFERENCE ON PRECISION AGRICULTURE, 5. 2000. Proceedings... CD-ROM. P. C. Robert et al., eds. Madison, Wisc.: ASA-CSSASSSA, 2000.

HEIL, K.; SCHMIDHALTER, U. Characterization of soil texture variability using the apparent soil electrical conductivity at a highly variable site. Computer \& Geosciences, Tarrytown, v. 39, p. 98-110, 2012. http://dx.doi.org/10.1016/j.cageo.2011.06.017

HOAGLIN, D.C.; MOSTELLER, F; TUKEY, J.W. Análise exploratória de dados: Técnicas robustas: um guia. Lisboa: Edições Salamandra, 1992. 446p.

ISLAM, M. M.; MEERSCHMAN, E.; SAEY, T.; DE SMEDT, P.; DE VIJVER, E. V. Comparing apparent electrical conductivity measurements on a paddy field under flooded and drained conditions. Precision Agriculture, Netherlands, v. 13, n. 3, p. 384-392, 2012. http://dx.doi.org/10.1007/s11119-011-9253-2

KACHANOSKI, R. G.; DE JONG, E. Scale dependence and the temporal persistence of spatial patterns of soil water storage. Water Resources Research, Washington, v. 24, n. 1, p. 85-91, 1988.

http://dx.doi.org/10.1029/WR024i001p00085

LI, Y.; SHI, Z.; LI, F. Delineation of site-specific management zones based on temporal and spatial variability of soil electrical conductivity. Pedosphere, Nanjing, v. 17, n. 2, p. 156-164, 2007.

http://dx.doi.org/10.1016/S1002-0160(07)60021-6

LIBARDI, P. L. Dinâmica da água no solo. v. 61, São Paulo: Ed. USP, 2005. 335p.

LIBARDI, P. L.; MANFRON, P. A.; MORAES, S. O. TUON, R. L. Variabilidade da umidade gravimétrica de um solo hidromórfico. Revista Brasileira de Ciência do Solo, Viçosa, v. 20, n. 1, p. 1-12, 1996.

MACHADO, P. L. O. A.; BERNARDI, A. C .C.; VALENCIA, L. I. O.; MOLIN, J. P.; GIMENEZ, L. M.; SILVA, C. A.; ANDRADE, A. G. A.; MADARI, B. E., MEIRELLES, M. S. P. M. Electrical conductivity mapping in relation to clay of a Ferralsol under no tillage system. Pesquisa Agropecuária Brasileira, Brasília, v. 41, n. 6, p. 1023-1031, 2006. http://dx.doi.org/10.1590/S0100-204X2006000600019 
MANN, K. K.; SCHUMANN, A. W.; OBREZA, T. A. Delineating productivity zones in a citrus grove using citrus production, tree growth and temporally stable soil data. Precision Agriculture, Netherlands, v. 12, n. 4, p. 457-472, 2011. http://dx.doi.org/10.1007/s11119-010-9189-y

MOLIN, J. P.; FAULIN, G. D. C. Spatial and temporal variability of soil electrical conductivity related to soil moisture. Scientia Agricola, Piracicaba, v. 70, n. 1, p. 1-5, 2013. http://dx.doi.org/10.1590/S010390162013000100001

MORETI, D.; LIBARDI, P. L.; ROCHA, G. C.; LOVATTI, M. J.; AGUIAR, L. I. G. Avaliação espaçotemporal das armazenagens gravimétricas e volumétricas da água num Latossolo com citros. Revista Brasileira de Ciências do Solo, Viçosa, v. 31, n. 6, p. 1281-1290, 2007. http://dx.doi.org/10.1590/S010006832007000600007

SERRANO, J. M.; PEÇA, J. O.; MARQUES DA SILVA, J. R.; SHAHIDIAN, S. Spatial and temporal stability of soil phosphate concentration and pasture dry matter yield. Precision Agriculture, Netherlands, v. 12, n. 2, p. 214-232, 2011. http://dx.doi.org/10.1007/s11119-010-9170-9

SERRANO, J. M.; SHAHIDIAN, S.; SILVA, J. R. M. Apparent electrical conductivity in dry versus wet soil conditions in a shallow soil. Precision Agriculture, Netherlands, v. 14, n. 1, p. 99-114, 2013.

http://dx.doi.org/10.1007/s11119-012-9281-6

SHI. Z.; WANG, K.; BAILEY, J. S.; JORDAN, C.; HIGGINS, A. H. Temporal changes in the spatial distributions of some soil properties on a temperate grassland site. Soil Use and Management, Oxford, v. 18, n. 4, p. 353-362, 2002. http://dx.doi.org/10.1079/SUM2002144

TERRÓN, J. M.; MARQUES DA SILVA, J. R.; MORAL, F. J.; GARCÍA-FERRER, A. Soil apparent electrical conductivity and geographically weighted regression for mapping soil. Precision Agriculture, Netherlands, v. 12, n. 5, p. 750-761, 2011. http://dx.doi.org/10.1007/s11119-011-9218-5

VACHAUD, G., PASSERAT DE SILANS, A., BALABANIS, P.; VAUCLIN, M. Temporal stability of spatially measured soil water probability density function. Soil Science Society of America Journal, Madison, v. 49, n. 4, p. $822-827,1985$.

VALENTE, D. S. M.; QUEIROZ, D. M.; PINTO, F. A. C.; SANTOS, N. T.; SANTOS, F. L. The relationship between apparent soil electrical conductivity and soil properties. Revista Ciência Agronômica, Fortaleza, v. 43, n. 4, p. 683-690, 2012a. http://dx.doi.org/10.1590/S1806-66902012000400009

VALENTE, D. S. M.; QUEIROZ, D. M.; PINTO, F. A. C.; SANTOS, N. T.; SANTOS, F. L. Definition of management zones in coffee production fields based on apparent soil electrical conductivity. Scientia Agricola, Piracicaba, v. 69, n. 3, p. 173-179, 2012b. http://dx.doi.org/10.1590/S0103-90162012000300001

WEBSTER, R.; OLIVER, M. A. Sample adequately to estimate variograms of soil properties. Journal of Soil Science, Oxford, v. 43, n. 1, p. 117-192, 1992. http://dx.doi.org/10.1111/j.1365-2389.1992.tb00128.x

XU, H.-W., WANG, K., BAILEY, J., JORDAN, C.; WITHERS, A. Temporal stability of sward dry matter and nitrogen yield patterns in a temperate grassland. Pedosphere, Nanjing, v. 16, p. 735-744, 2006.

http://dx.doi.org/10.1016/S1002-0160(06)60109-4 